\title{
Bioactive Properties of Different Parts of Vitis labrusca L. Fruit
}

\author{
Ilkay KOCA, Belkis TEKGULER*, Burçin TURKYILMAZ
}

\author{
Ondokuz Mayıs University, Engineering Faculty, Food Engineering Department, Samsun, Turkey \\ ORCID ID: Ilkay KOCA: https:/ / orcid.org/0000-0001-6089-8586; Belkis TEKGULER: https:/ / orcid.org/0000-0001-7850-8013; Burçin \\ TURKYILMAZ: https://orcid.org/0000-0001-8949-5852
}

\begin{abstract}
Received: 31.10 .2021 Accepted: 15.12 .2021 Published online: 20.12 .2021 Issue published: 31.12 .2021

Abstract: Vitus labrusca L. is a fragrant grape variety that is widely grown in our country and the world. In addition to being consumed as a table grape, it is also consumed by processing into different products such as wine, vinegar, and molasses. This fruit and its residues, revealed after processing into the product, are rich in phenolic compounds. The residues of the grape can be evaluated due to their bioactive potential. In this study, the bioactive characteristics of $V$. labrusca L. grown in Samsun were investigated. Total phenolic, antioxidative activity properties and oleanolic acid levels were determined in order to reveal their bioactive properties. For this purpose, the whole fruits, skin, and seed parts of the fruits were analyzed separately. It is concluded that the highest values as the total phenolics $\left(1519.68 \pm 280.05 \mathrm{mg} \mathrm{kg}^{-1}\right)$, oleanolic acid $\left(351.32 \pm 91.42 \mathrm{mg} \mathrm{kg}^{-1}\right)$, and antioxidant values (FRAP: $22.13 \pm 6.77 \mu \mathrm{mol} \mathrm{Fe}{ }^{2+} \mathrm{g}^{-1}$ ) were determined in the skin of fruit. Furthermore, when the relationship between the natural antioxidant contents and the antioxidant activity examined, there was a negative correlation between the total phenolics and DPPH reducing value (as EC $\mathrm{E}_{50}$ ). In conclusion, it is considered that the residues of the grape should be evaluated for their bioactive potential due to $V$. labrusca L. Fruits being rich in bioactive compounds, and these compounds are mainly concentrated in the skin part.
\end{abstract}

Keywords: Antioxidant activity, grape, oleanolic acid, triterpenoids.

\section{Vitis labrusca L. Meyvesinin Farklı Kısımlarının Biyoaktif Özellikleri}

\begin{abstract}
Öz: Vitus labrusca L. ülkemizde ve dünyada yaygın olarak yetiştirilen kokulu bir üzüm çeşididir. Sofralık üzüm olarak tüketilmesinin yanı sıra şarap, sirke ve pekmez gibi farklı ürünlere işlenerek de tüketilmektedir. Bu meyve ve ürüne işlendikten sonraki kalıntıları fenolik bileşikler açısından zengindir. Üzüm kalıntıları biyoaktif potansiyelleri nedeniyle değerlendirilebilir. Bu çalışmada, Samsun'da yetiştirilen V. labrusca L.'nın biyoaktif özellikleri araştırılmıştır. Biyoaktif özelliklerini ortaya koymak için toplam fenolik madde, antioksidan aktivite özellikleri ve oleanolik asit miktarları belirlenmiştir. Bu amaçla meyveler bütün olarak, kabuk ve çekirdek kısımları ayrı ayrı analiz edilmiştir. Toplam fenolik madde $\left(1519.68 \pm 280.05 \mathrm{mg} \mathrm{kg}^{-1}\right)$, oleanolik asit $\left(351.32 \pm 91.42 \mathrm{mg} \mathrm{kg}^{-1}\right)$ ve antioksidan aktivite değerleri (FRAP: $22.13 \pm 6.77 \mu \mathrm{mol} \mathrm{Fe}^{2+} \mathrm{g}$ 1) en fazla meyvelerin kabuk kısmında belirlenmiştir. Ayrıca, doğal antioksidan içerikleri ile antioksidan aktivite arasındaki ilişki incelendiğinde, toplam fenolik madde ile DPPH indirgeme değeri (EC50 olarak) arasında negatif bir ilişki olduğu görülmüştür. Sonuç olarak, $V$. labrusca L. meyvelerinin biyoaktif bileşiklerce zengin olması ve bu bileşiklerin ağırlıklı olarak kabuk kısmında yoğunlaşması nedeniyle üzüm kalıntılarının biyoaktif potansiyelleri açısından değerlendirilmesi gerektiği düşünülmektedir.
\end{abstract}

Anahtar kelimeler: Antioksidan aktivite, üzüm, oleanolik asit, triterpenoidler.

\section{Introduction}

Studies have shown an inverse relationship between agerelated diseases and fruit and vegetable consumption due to antioxidants and especially phenolics in fruits and vegetables (Boas et al., 2014).

Grape is widely consumed and used to produce wine, vinegar, and molasses in the world. It has also been used to cure various diseases in traditional medicine (Liu et al., 2012). Mainly, its therapeutic potential has resulted from numerous phenolic compounds like flavonoids (anthocyanins, flavanols, and flavonols), phenolic acid, and resveratrol found in grapes. In addition, the grape phenolics have antiatherosclerotic, antithrombotic, and anti-inflammatory effects due to antioxidant activities (Carrieri et al., 2013).

The grape skin is present at about $5-10 \%$ of the total dry weight of grape berry. It is a hydrophobic barrier against UV-C light, dehydration, physiological and climatic injuries, and fungal infection. Generally, there are five layers on the grape skin from outside to inside: 1. epicuticular wax layer; 2. cuticle proper; 3. cutinized layer; 4. pectic layer, and 5. non cutinized cellulose layer or cellulose layer. Next to the epidermis, hypodermis including many phenolic compounds, has a few cell layers (Fava et al., 2011).

The main functions of the fruit cuticle, the hydrophobic coating on the epidermis are the prevention of dehydration by diminishing water loss and the inhibition of leaching of organic and inorganic compounds from inner tissues (Pensec et al., 2014). The first preventive barrier against abiotic and biotic environmental stresses is the cuticle. The cuticle is the exterior mechanical support, hence maintaining fruit wholeness. This support is crucial for fruits that have soft tissue (Pensec et al., 2014; Lara et al., 2019).

Cuticles are formed from two classes of lipids: very

*Corresponding author: belkisg@omu.edu.tr 
long-chain fatty acids and lipids derived from isoprene. In cuticular waxes, the lipids, derived from isoprene, are pentacyclic triterpenes and steroids. These triterpenoids have many biological functions and a lot of pharmacological effects against biotic stress (Pensec et al., 2014).

Oleanolic acid, a natural triterpenoid, is widely distributed in food, therapeutic herbs, and other plants. The oleanolic acid is in grape berries, especially in their skin (Chronopoulou et al., 2013). In recent years, there have been studies on its biological and pharmacological significance. The oleanolic acid and some of its derivatives show exciting properties such as hepatoprotective, antiinflammatory, anti-HIV, and antitumor activities (Chronopoulou et al., 2013; Ayeleso et al., 2017). Kang et al. (2021) determined that oleanolic acid prevents allergic inflammatory reaction by blocking the NF-kB and STAT1 signaling pathways and oleanolic acid diminishes the levels of histamine and immunoglobulin-E.

The parts rich in terpenoids and phenolic compounds are separated when processing into grape juice and wine (Dwyer et al., 2014). It has been reported that the phenolics in grapes and red wines, which are known to have positive effects on health, inhibit the oxidation of low-density lipoproteins (LDL) in vitro (Jayaprakasha et al., 2003). For example, during wine production, approximately $25 \%$ of the grape weight is separated as waste. Currently, this residue part of the grape is used as compost in agricultural areas. Therefore, it is important to know the potential of such a waste that is rich in bioactive compounds to be converted into products with high added value in food industry as functional foods, in cosmetic industry as cosmetic agents, and as food supplements due to their pharmaceutical properties (Jayaprakasha et al., 2003; Dwyer et al., 2014).

This study aimed to assess the natural antioxidant compounds, total phenolics, the relationship between the oleanolic acid presence, and the in vitro antioxidant activities of whole fruit, seed, and skin extracts of Vitis labrusca L. grape (common name "kokulu üzüm") variety from Samsun, Turkey.

\section{Material and Methods}

This study was carried out in the food engineering department laboratories of Ondokuz Mayis University. Grape (Vitis labrusca L.) samples, cultivated in Samsun, were purchased from seven different local markets at the end of the summer season of 2016. After the samples were washed and the unnecessary parts were removed, each fruit sample was separated into two groups of $200 \mathrm{~g}$. The first group was analyzed as whole. These fruits were homogenized by waring blender. In the second group, however, the seeds and skins of the fruits were manually separated. Then, the seeds and the skins were weighed and ground in a conventional electric grinder just before the analysis while the second one was analyzed separately as skins and seeds. The fruits in first group were homogenized by waring blender.

\subsection{Extraction of Antioxidants}

Ultrasound-assisted extraction was done by the use of ultrasonic bath (Sonorex, Bandelin). The samples (10 g) were placed into a conical flask including $25 \mathrm{~mL}$ of methanol as solvent, and sonicated for $15 \mathrm{~min}$ at $40^{\circ} \mathrm{C}$ temperature. The extraction process was carried out three times with fresh portions of solvent in the conditions mentioned above.

\subsection{Physical-chemical analysis}

The whole fruits were analyzed for soluble solid content (Brix), pH, and dry matter according to AOAC (2000). Dry matter analysis were done in the skin and seed parts of grape. For dry matter analysis, the sample was dried in the oven with a vacuum $(100 \mathrm{~mm}-\mathrm{Hg})$ at $70^{\circ} \mathrm{C}$ until obtaining the constant weight.

\subsection{Color Analysis}

The surface color of grape berry was measured with a tristimulus reflectance colorimeter Model CR-400 (Minolta Co., Japan). Values were obtained for $\mathrm{C}$ illuminant and $2^{\circ}$ observer. Before the test, the instrument was calibrated with a standard white provided by the manufacturer. The $L^{*}, a^{*}, b^{*}$ components are CIELAB space. $L^{*}$ indicates lightness or luminance. $\mathrm{a}^{*}$ represents green $(-)$ to red $(+)$ axis, and $b^{*}$ represents blue $(-)$ to yellow $(+)$ axis.

\subsection{Determination of natural antioxidants}

\subsubsection{Total phenolic compounds}

The total phenolic content of each extract was determined according to the Folin-Ciocalteau colorimetric method (Singleton \& Rossi, 1965). Absorbance was read at $760 \mathrm{~nm}$ and results were expressed as gallic acid equivalents $(\mathrm{mgGAE} \mathrm{kg-1})$.

\subsubsection{Total anthocyanins content}

Total anthocyanins content was determined by the $\mathrm{pH}$ differential method (Wrolstad, 1976). For this aim, the extracts were set to $\mathrm{pH} 1.0$ and 4.5 with buffers. The absorbance of each solution was measured at a wavelength of maximum absorption and $700 \mathrm{~nm}$. The difference in the absorbance values at $\mathrm{pH} 1.0$ and 4.5 was directly proportional to the total anthocyanin concentration expressed in malvidin 3.5-diglucoside.

\subsubsection{Oleanolic acid determination}

The oleanolic acid was determined using HPLC-DAD according to the procedure described by Zhang et al. (2013). HPLC-DAD analyses were performed on a Shimadzu HPLC system equipped with Class Vp software (ver. 6.14 SP2), a binary gradient (LC20 AT) pump a DAD detector (SPD-M20A), and a system controller (CBM-20A). Also, there was an autosampler (SIL-20A) with a $20 \mu \mathrm{L}$ sample loop. The column used was PAH Ultimate XBPAH column $(4.6 \times 250 \mathrm{~mm}, 5 \mu \mathrm{m}$, Welch Materials, USA). The wavelength was set at $210 \mathrm{~nm}$. The mobile phase containing $85 \%$ acetonitrile and $15 \%$ ultra-distilled water was used at the flow rate of $1.0 \mathrm{~mL} \mathrm{~min}^{-1}$. A stock solution containing $200 \mu \mathrm{g} \mathrm{mL}-1$ of oleanolic acid standard was prepared in methanol and diluted to a series of convenient concentrations to set the calibration curve.

\subsubsection{1,1-diphenyl-2-picrylhydrazyl (DPPH) free radical scavenging activity analysis}

The DPPH method was performed as described by Tural and Koca (2008) with some modifications. The reduction in the absorbance of $100 \mu \mathrm{M}$ DPPH radicals, $(1 \mathrm{~mL})$ dissolved in $80 \%$ methanol, by the addition of each extract 
was measured at $515 \mathrm{~nm}$ after 180 minutes.

Trolox (a water soluble vitamin E analog) was used as positive control. Radical scavenging activity was expressed as the inhibition percentage and was calculated using the following formula:

Inhibition $\%=\left[\left(A_{\text {blank }}-A_{\text {sample }}\right) / A_{\text {blank }}\right] \times 100$

Where $\mathrm{A}_{\text {blank }}$ is the absorbance of the blank (containing methanol instead of sample) and $\mathrm{A}_{\text {sample }}$ is the absorbance of the extracts or control. The half maximal inhibitory concentration $\left(\mathrm{EC}_{50}\right)$ value for each extract was calculated from the plotted graph of scavenging activity against the concentrations of the sample.

\subsubsection{The ferric reducing/antioxidant power (FRAP) analysis}

The direct measurement of antioxidant (reducing) ability thanks to the reduction of the complex $\mathrm{Fe}^{3+}$ /tripyridyltriazine (TPTZ) to $\mathrm{Fe}^{2+}$ at acid $\mathrm{pH}$ was carried out by using the FRAP method, which is defined by Benzie and Szeto (1999). FRAP was calculated from a calibration curve using $\mathrm{FeSO}_{4}$ as the standard and expressed as $\mu \mathrm{mol} \mathrm{FeSO}_{4}$ equivalents per $\mathrm{g}\left(\mu \mathrm{mol} \mathrm{Fe}{ }^{2+} \mathrm{g}^{-1}\right)$.

\subsection{Statistical analysis}

The data were statistically evaluated by ANOVA and Duncan tests (ver. 21.0, SPSS) at a 0.05 level of significance. All the data was also subjected for correlation analyses using Pearson's correlation coefficient.

Table 1. Some physical properties of whole fruits analyzed

\begin{tabular}{|c|c|c|c|c|c|c|c|}
\hline Sample number & Skin $\%$ & Seed $\%$ & $L^{*}$ & $+a^{*}$ & $+b^{*}$ & Soluble solids \% (Brix) & $\mathrm{pH}$ \\
\hline 1 & 24.43 & 9.20 & 20.68 & 4.91 & 2.44 & 20.00 & 3.99 \\
\hline 2 & 32.14 & 14.70 & 16.56 & 5.35 & 1.73 & 20.00 & 3.67 \\
\hline 3 & 31.26 & 8.50 & 19.57 & 5.99 & 0.97 & 18.00 & 3.73 \\
\hline 4 & 26.56 & 6.71 & 19.16 & 5.44 & 1.74 & 19.00 & 3.60 \\
\hline 5 & 25.76 & 6.95 & 20.92 & 7.11 & 2.32 & 19.00 & 3.74 \\
\hline 6 & 30.58 & 10.93 & 22.63 & 6.30 & 3.77 & 16.00 & 3.68 \\
\hline 7 & 26.63 & 5.85 & 21.04 & 8.25 & 1.79 & 18.50 & 4.06 \\
\hline
\end{tabular}

Where $L^{*}$ is luminescens $\left(L^{*}=0\right.$, black; $L^{*}=100$, white); $a^{*}$ is redness and greenness $\left(+60\right.$, red; -60 , green) and the $b^{*}$ value represents yellowness and blueness $(+60$, yellow; -60 , blue).

Table 2. Antioxidant properties of the whole fruits and their skin and seeds

\begin{tabular}{|c|c|c|c|c|c|c|c|}
\hline & Sample number & $\begin{array}{c}\text { Dry matter } \\
\%\end{array}$ & $\begin{array}{c}\text { Total phenolics } \\
\mathrm{mg} \mathrm{kg}^{-1}\end{array}$ & $\begin{array}{c}\text { Total antocyanins } \\
\text { mg } 100 \mathrm{~g}^{-1}\end{array}$ & $\begin{array}{c}\text { Oleanolic acid } \\
\mathrm{mg} \mathrm{kg}^{-1}\end{array}$ & $\begin{array}{c}\text { FRAP } \\
\mu \mathrm{mol} \mathrm{Fe}^{2+} \mathrm{g}^{-1}\end{array}$ & $\begin{array}{c}\mathrm{EC}_{50} \\
\mathrm{mg} \mathrm{mL}^{-1} \\
\end{array}$ \\
\hline \multirow{7}{*}{ 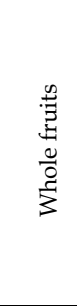 } & 1 & 25.60 & 409.44 & 32.73 & 128.54 & 7.63 & 9.24 \\
\hline & 2 & 25.80 & 418.33 & 79.81 & 122.07 & 9.30 & 10.25 \\
\hline & 3 & 25.20 & 515.56 & 56.83 & 161.24 & 11.27 & 8.75 \\
\hline & 4 & 23.40 & 431.67 & 113.97 & 187.04 & 10.64 & 11.25 \\
\hline & 5 & 24.00 & 476.67 & 69.41 & 139.16 & 10.92 & 9.49 \\
\hline & 6 & 18.25 & 355.56 & 14.91 & 272.22 & 10.27 & 14.79 \\
\hline & 7 & 22.55 & 504.44 & 18.60 & 238.99 & 11.96 & 9.14 \\
\hline Mean & & $23.54 \pm 2.62 \mathrm{c}$ & $444.52 \pm 57.25 b$ & $55.18 \pm 35.90 \mathrm{ab}$ & $178.47 \pm 57.79 \mathrm{~b}$ & $10.28 \pm 1.43 b$ & $10.42 \pm 2.10 \mathrm{~b}$ \\
\hline \multirow{7}{*}{$\frac{\tilde{a}}{\omega}$} & 1 & 32.47 & 1868.89 & 29.81 & 337.33 & 26.03 & 2.21 \\
\hline & 2 & 50.30 & 1626.67 & 44.87 & 314.75 & 26.48 & 2.23 \\
\hline & 3 & 34.14 & 1333.33 & 110.70 & 245.74 & 19.16 & 3.01 \\
\hline & 4 & 30.53 & 1686.11 & 247.65 & 522.08 & 32.65 & 1.75 \\
\hline & 5 & 30.28 & 1497.78 & 397.49 & 417.90 & 21.32 & 2.53 \\
\hline & 6 & 31.39 & 1005.56 & 27.48 & 293.72 & 12.54 & 4.68 \\
\hline & 7 & 33.03 & 1619.44 & 104.49 & 327.71 & 16.75 & 3.01 \\
\hline Mean & & $34.59 \pm 7.06 \mathrm{~b}$ & $1519.68 \pm 280.05 a$ & $137.49 \pm 137.73 a$ & $351.32 \pm 91.42 \mathrm{a}$ & $22.13 \pm 6.77 a$ & $2.77 \pm 0.95 c$ \\
\hline \multirow{7}{*}{ జ్ّ } & 1 & 40.95 & 407.78 & 15.37 & 40.95 & 5.03 & 39.68 \\
\hline & 2 & 40.56 & 322.22 & 20.80 & 40.55 & 6.67 & 13.37 \\
\hline & 3 & 53.91 & 304.44 & 32.29 & 53.90 & 5.98 & 21.53 \\
\hline & 4 & 42.83 & 372.78 & 13.04 & 42.82 & 7.49 & 16.39 \\
\hline & 5 & 40.24 & 457.22 & 2.17 & 40.23 & 8.01 & 10.81 \\
\hline & 6 & 44.53 & 161.11 & 4.34 & 44.53 & 3.42 & 18.53 \\
\hline & 7 & 39.80 & 149.44 & 10.71 & 39.80 & 3.84 & 18.52 \\
\hline Mean & & $43.26 \pm 4.98 \mathrm{a}$ & $310.713 \pm 117.83 b$ & $14.10 \pm 10.23 b$ & $43.25 \pm 4.98 \mathrm{c}$ & $5.78 \pm 1.76 b$ & $19.83 \pm 9.44 a$ \\
\hline
\end{tabular}

*There is no statistical difference between those shown with the same letter in the same column ( $>>0.05)$.

${ }^{* *}$ As positive control, Trolox were $50.70 \mu \mathrm{mol} \mathrm{g}{ }^{-1}$ and $66.54 \mu \mathrm{g} \mathrm{mL}^{-1}$ for FRAP and $\mathrm{EC}_{50}$, respectively. 


\section{Results and Discussion}

The physical properties of the fruits were given in Table 1 , while the antioxidant analysis results for whole fruits, the seeds, and skins of the samples were shown in Table 2. As seen in Table 1, the skin weight of fruits and seed weight were ranged between 24.43 and $32.14 \%, 5.85-14.70 \%$, respectively. The total soluble solids of the samples ranged between 16.0 and $20.0 \%$ and their $\mathrm{pH}$ values ranged between 3.60 and 4.06 .

As it is known, the color of food affects the taste of the consumer (Benmeziane et al., 2016). Anthocyanins, the phenolic compounds, are responsible for the color of grapes (Yamamoto et al., 2015). Anthocyanins are affected by many factors including temperature, light, $\mathrm{pH}$, metal ions, and oxygen, etc. (Benmeziane et al., 2016). Color values in fruits are expressed with $\mathrm{L}^{*}$ (brightness: 100, white; 0 , black), $\mathrm{a}^{*}\left(+\right.$, red; -, green), and $\mathrm{b}^{*}(+$, yellow; -, blue). A lower $L^{*}$ value of grapes means a darker skin color (Yamamoto et al., 2015). In this study, the color values were examined and it was seen that the fruit color was dark purple or close to black. Additionally, it has been thought that the waxy layer on the surface of a grape creates a difference between the color values. It was found that there was no statistically significant correlation between the total anthocyanin content and the color values in the studied samples. However, it was observed that the total amount of anthocyanin was highest in the skin.

As seen in Table 2, the total phenolics, the total anthocyanins, oleanolic acids, and FRAP values were the highest while the $\mathrm{EC}_{50}$ value was the lowest in the skin part. These values were statistically significant $(p<0.05)$.

Carrieri et al. (2013) studied 12 table grape varieties (white, red, and black) and found that the total polyphenols in the grape extracts ranged from $81 \mathrm{mg} \mathrm{kg}^{-1}$ to $355 \mathrm{mg} \mathrm{kg}^{-1}$ in fresh weight. The highest polyphenolic content $\left(297 \mathrm{mg} \mathrm{kg}^{-1}\right)$ was found in the black grapes while the lowest (138 $\left.\mathrm{mg} \mathrm{kg}^{-1}\right)$ phenolic value was for red grapes. The white grapes had no anthocyanins, but there was an intermediate content $\left(196 \mathrm{mg} \mathrm{kg}^{-1}\right)$. In present study, total phenolics and anthocyanins were higher than their findings.

In a study involving Vitis labrusca L., antioxidant activity, proximate composition, phenolic compounds, trans-resveratrol, and fatty acid contents of peel, pulp, and seeds of four grape varieties were determined by Santos et al. (2011). They found that for $50 \%$ inhibition of DPPH, the lowest concentrations necessary were (9.26 to $126.91 \mu \mathrm{g}$ $\left.\mathrm{mL}^{-1}\right)$ in seeds. Additionally, these researchers concluded that the total phenolic content varied between 0.04 and $122.35 \mathrm{mg} \mathrm{g}^{-1}$, the highest phenolic concentrations (89.83 to $122.35 \mathrm{mg} \mathrm{g}^{-1}$ ) were in seeds, and the pulp had no antioxidant activity (Santos et al., 2011). Baydar et al. (2004) found that the quantities of total phenolics extracted with various solvent mixtures varied from 627.98 to 667.87 mgGAE g-1 in grape seed extracts and 29.55 to 45.44 mgGAE g-1 in grape bagasse extracts. The highest phenolic contents were in the grape seed extracts while grape bagasse extracts gave the lowest phenolic contents. They concluded that the phenolic compound contents of the seed extracts were higher than the phenolic contents of the grape skin extracts. According to their findings, the phenolic values for seed were higher than the ones in this study. On the contrary, the total phenolic content was the highest in the skin part of the samples in the present study. There is increasing evidence about grape skins stating that they are rich in phenolics such as anthocyanins and flavonols (Georgiev et al., 2014; Shahidi \& Ambigaipalan, 2015; Sabra et al., 2021). Lago-Vanzela et al. (2011) determined that $93.7 \%$ of the total phenolic content was distributed in the skin of the Bordo grape ( $\mathrm{V}$. labrusca) cultivated in South Brazil. As a result of this study, it was revealed that the total phenolic matter contents of the whole fruit, skin, and seed parts were lower than the findings of Baydar et al. (2004), Rockenbach et al. (2011a), and Santos et al. (2011) but higher than the findings of Carrieri et al. (2013).

In another study, Rockenbach et al. (2011b) found that the total phenolic, anthocyanin, DPPH, and FRAP values of the Vitis labrusca L. pomace in dry weight were $32.62 \mathrm{mg} \mathrm{g}^{-1}, 1.84 \mathrm{mg} \mathrm{g}^{-1}, 188.02 \mu \mathrm{mol} \mathrm{g}^{-1}$ and $4117.79 \mu \mathrm{mol}$ $\mathrm{g}^{-1}$, respectively. The anthocyanin values of the present study were higher than the findings of Rockenbach et al. (2011b).

There are two mechanisms based on single-electron transfer and hydrogen atom transfer that can be used to determine the antioxidant activity. In vitro antioxidant activity of foods should be performed based on both mechanisms (Samavardhana et al., 2015). Ferric ion is frequently used as a mark of electron-donating activity in the FRAP method. The antioxidants in the samples act as reductants in a redox-linked colorimetric reaction. The value reflects the reducing power of the antioxidants (Shao et al., 2016). The extract has the ability to scavenging of free radicals thanks to hydrogen donation. DPPH is a stable free radical that is reduced to diphenyl picryl hydrazine through a reaction with antioxidant compounds. The initial reaction mixture has a deep violet color that changed to light yellow after reducing DPPH (Kobra et al., 2019). In the present study, DPPH and FRAP methods were used and the results were given in Table 2. DPPH radical scavenging activities of the extracts were accounted as $\mathrm{EC}_{50}$ values. $\mathrm{EC}_{50}$ is an efficient concentration of the extract required for $50 \%$ scavenging of DPPH. Trolox was $66.54 \mu \mathrm{g} \mathrm{mL}^{-1}$ for $50 \%$ scavenging of DPPH $\left(\mathrm{EC}_{50}\right)$ as a positive control. However, the $\mathrm{EC}_{50}$ mean values were $10.42 \pm 2.10 \mathrm{mg} \mathrm{mL}^{-1}$ in whole fruits, $2.77 \pm 0.95$ $\mathrm{mg} \mathrm{mL}^{-1}$ in the skin, and $19.83 \pm 9.44 \mathrm{mg} \mathrm{mL}^{-1}$ in the seed samples. The skin parts had the highest radical scavenging power. The values of the skin parts were lower than the Trolox (66.54 $\left.\mu \mathrm{g} \mathrm{mL}^{-1}\right)$ about 40 times. As comparing the FRAP values with the Trolox (positive control $50.70 \mu \mathrm{mol}$ $\left.\mathrm{g}^{-1}\right)$, the FRAP mean value $\left(22.13 \pm 6.77 \mu \mathrm{mol} \mathrm{Fe}{ }^{2+} \mathrm{g}^{-1}\right)$ was about half of Trolox in the skin parts. The FRAP values of the grape skin in our study were higher than the findings of Rockenbach et al (2011a). They determined the total phenolic and FRAP values of Vitis labrusca L. as $1839 \mathrm{mg}$ $100 \mathrm{~g}^{-1}$ dry weight (skin), $2128 \mathrm{mg} \mathrm{100g-1}^{-1}$ dry weight (seed), and $4362 \mu \mathrm{mol} 100 \mathrm{~g}^{-1}$ (skin), $2942 \mu \mathrm{mol} 100 \mathrm{~g}^{-1}$ (seed), respectively.

Oleanolic acid, which has antioxidant properties especially in the skin part, was determined using HPLCDAD. In the present study, according to the obtained chromatograms, the oleanolic acid retention times in the samples ranged from 14.0 minutes to 14.5 minutes (Fig. 1). 
Oleanolic acid treatment is effective on oxidative stress which is a significant factor in developing different diseases such as liver disorders, inflammation, cancer, and diabetes (Ayeleso et al., 2017). However, there are relatively few studies regarding grape triterpenic acid contents, including oleanolic acid. The quantitative oleanolic acid data obtained were lower than the findings reported by Pensec et al. (2014) while they were higher than results reported by Orbán et al. (2009).

The triterpenoid contents and compositions of the waxy cuticular layer of eight grape cultivars were investigated by Pensec et al. (2014) at some phenological stages: young grapes, grapes at veraison, and mature grapes. According to their findings, the total triterpenoid levels were high in young grapes and fruit development the neutral triterpenoid levels showed a slight increase; however, the total triterpenoid levels progressively decreased. They stated that the oleanolic aldehyde was the most dominant triterpenoid among neutral triterpenoids. They concluded that the oleanolic acid levels, which were the highest in the wax extract of young grapes, were 406 $\mu \mathrm{g} \mathrm{mg} \mathrm{m}^{-1}$ in Muscat d'Alsace and $782 \mu_{\mathrm{g} \mathrm{mg}} \mathrm{m}^{-1}$ in Sylvaner, and these levels decreased during fruit maturation (Pensec et al., 2014).
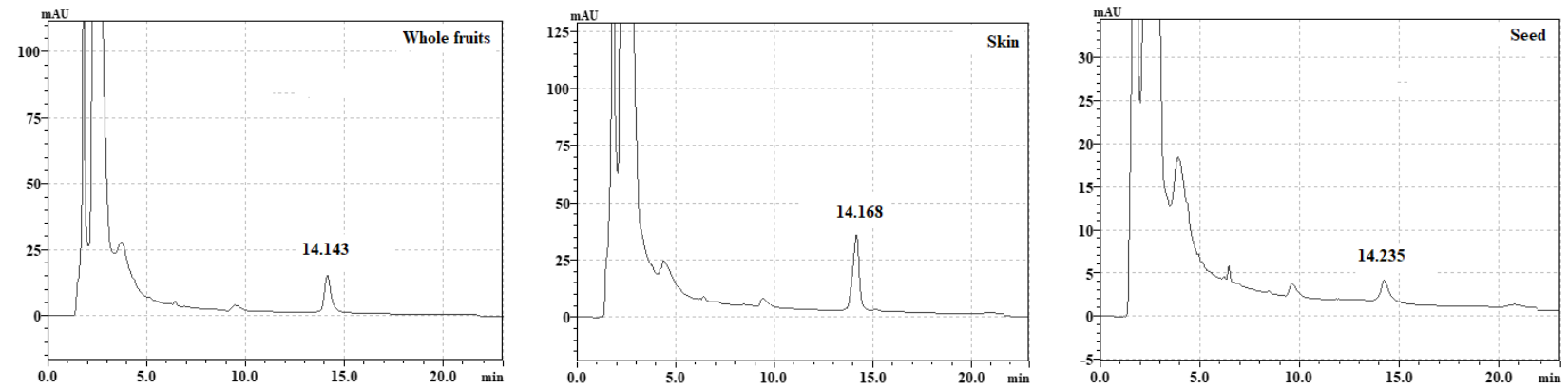

Figure 1. Oleanolic acid Chromatograms of the whole fruits and their skin and seeds

In another investigation, Orbán et al. (2009) revealed that the content of the dominant triterpenes in the skin and cuticular wax of grape berries highly varied related to grape varieties by liquid chromatography-mass spectrometry. The oleanolic acid levels ranged from 157.43 $\mathrm{mg} \mathrm{kg}^{-1}$ to $239.19 \mathrm{mg} \mathrm{kg}^{-1}$ in red grape skin and $31.53 \mathrm{mg}$ $\mathrm{kg}^{-1}$ to $162.01 \mathrm{mg} \mathrm{kg}^{-1}$ in cuticular wax. In the present study, the lowest oleanolic acid values (Table 2) were in the seed parts in our samples but the oleanolic acid values in the skin were higher than their findings.

De Nisco et al. (2013) reported that the total antioxidant activity was higher for fruit skin extracts than the whole fruits (about 2- to 4-fold). Burin et al. (2010) have reported that the phenolic composition of grape fruits influenced their antioxidant activities.

In the present study, to find out the contribution of natural antioxidants to the antioxidant activity of the fruits, a correlation coefficient was obtained between the total phenolics, total anthocyanins, oleanolic acid values, and antioxidant activity values in different parts of the grape fruits. When the results for these parts of the fruit were analyzed among themselves, there was a very significant correlation $(\mathrm{p}<0.01)$ between total phenolics and $\mathrm{EC}_{50}$ values $\left(\mathrm{r}=-0.886^{* *}\right)$ and between FRAP and $\mathrm{EC}_{50}$ values $\left(\mathrm{r}=-0.912^{* *}\right)$ in the skin (according to Pearson correlation). Besides, there was a significant $(p<0.05)$ relation between total phenolics and FRAP values $\left(\mathrm{r}=0.831^{*}\right)$ as well as between total phenolics and $\mathrm{EC}_{50}(\mathrm{r}=-$ $\left.0.802^{*}\right)$ in the seed part and the whole fruit. In a study investigating total phenolic content, color, and antioxidant activity in commercial, organic, and homemade grape juices, Burin et al. (2010) found a vigorously positive correlation between the antioxidant activity and total phenolic content for the commercial juice. Our results were consistent with the literature.

Vitis labrusca L. grape variety is consumed by people as table grape. In addition, this grape is used to produce fruit juice, molasses, vinegar, and wine. The residue of grapes, which is released when processed into products such as fruit juice, molasses, vinegar, and wine, are rich in bioactive compounds. Therefore, the whole fruit, the skin, and the grape seed were separately analyzed in this study. It was determined that bioactive compounds such as oleanolic acid and total phenolic compounds were concentrated in the skin. In the study, skin and seed separation was carried out under controlled conditions in the laboratory. Therefore, it may not fully reflect the losses of bioactive components during processing in the actual production process. From this point of view, further studies are needed to determine the losses in the production process and the bioactive components in the residue. The characteristics of the soil in which the plant is grown, agricultural production conditions, and the region where it is grown affect the composition of plant products. The study only reflects the results of samples from different local markets in Samsun.

\section{Conclusion}

As a result of this study, it was found that natural antioxidant substances of Vitis labrusca L. Fruits such as total phenolics, total anthocyanins, and oleanolic acids concentrated in the skin part, and the antioxidant activity was very high compared with fruit seeds. These findings are parallel with general literature information. When compared with whole fruit, it was seen that the fruit skin had about three times more total phenolic and two times more oleanolic acid. According to the findings, the grape skin is a potential source of oleanolic acid, an important bioactive compound. In conclusion, V. labrusca L. fruits are rich in bioactive compounds and these compounds are mainly concentrated in the skin part. Therefore, the residues of the grape should be evaluated due to their bioactive potential. 
Acknowledgements: This study was supported by Project Management Office of Ondokuz Mayıs University under number PYO.MUH.1904.15.020

Ethics committee approval: Ethics committee approval is not required for this study.

Conflict of interest: The authors declare that there is no conflict of interest.

\section{References}

AOAC, (2000). Official Methods of Analysis of the Association of Official Analysis Chemists (17th ed). AOAC International, Gaithersburg, MD.

Ayeleso, T.B., Matumba M.G., \& Mukwevho, E. (2017). Oleanolic acid and its derivatives: biological activities and therapeutic potential in chronic diseases. Molecules, 22(11), 1915. https://doi.org/10.3390/molecules22111915

Baydar, N.G., Ozkan, G., \& Sagdic, O. (2004). Total phenolic contents and antibacterial activities of grape (Vitis vinifera L.) extracts. Food Control, 15, 335-339. https:// doi.org/10.1016/S0956-7135(03)00083-5

Benmeziane, F., Cadot,Y., Djamai, R., \& Djermoun, L. (2016). Determination of major anthocyanin pigments and flavonols in red grape skin of some table grape varieties (Vitis vinifera sp.) by high-performance liquid chromatography-photodiode array detection (HPLC-DAD). OENO One, 50(3), 125-135. https:// hal.archives-ouvertes.fr/hal-01606633

Benzie, I.F.F., \& Szeto, Y.T. (1999). Total antioxidant capacity of teas by the ferric reducing/antioxidant power assay. Journal of Agricultural and Food Chemistry, 47(2), 633-636. https://doi.org/10.1021/if9807768

Boas, A.C.V., Henrique, P.C., Lima, L.C.O., \& Neto, A.D. (2014). Antioxidant activity, anthocyanins and organic acids content of grape juices produced in southwest of Minas Gerais. Brazil Ciência e Agrotecnologia Lavras, 38, 480-486. https:// doi.org/10.1590/S1413-70542014000500007

Burin, V.M., Falcão, L.D., \& Gonzaga, L.V. (2010). Colour, phenolic content and antioxidant activity of grape juice. Ciência e Tecnologia de Alimentos, 30(4), 1027-1032. https:/ / doi.org/10.1590/S0101-20612010000400030

Carrieri C., Milella R.A., Incampo F., Crupi P., Antonacci D., Semeraro N., \& Colucci M. (2013). Antithrombotic activity of 12 table grape varieties. Relationship with polyphenolic profile. Food Chemistry 140(4), 647-653. https:// doi.org/10.1016/j.foodchem.2012.10.132

Chronopoulou, L., Agatone, A.C., \& Palocci, C. (2013). Supercritical $\mathrm{CO}_{2}$ extraction of oleanolic acid from grape pomace. International Journal of Food Science \& Technology, 48(9), 1854-1860. https://doi.org/10.1111/ifs.12161

De Nisco M., Manfra M., Bolognese, A., Sofo A., Scopa A., Tenore G.C.,... \& Russo M.T. (2013). Nutraceutical properties and polyphenolic profile of berry skin and wine of Vitis vinifera L. (cv. Aglianico). Food Chemistry, 140(4), 623-629. https://doi.org/10.1016/j.foodchem.$\underline{2012.10 .123}$

Dwyer, K., Hosseinian, F., \& Rod, M. (2014). The market potential of grape waste alternatives. Journal of Food Research, 3(2), 91-106. https://doi.org/10.5539/jfr.v3n2p91

Fava J., Hodara K., Nieto, A., Guerrero S., Alzamora S.M., \& Castro M.A. (2011). Structure (micro, ultra, nano), color and mechanical properties of Vitis labrusca L. (grape berry) fruits treated by hydrogen peroxide, UV-C irradiation and ultrasound. Food Research International, 44(9), 2938-2948. https://doi.org/10.1016/j.foodres.2011.06.053

Georgiev, V., Ananga, A., \& Tsolova, V. (2014). Recent advances and uses of grape flavonoids as nutraceuticals. Nutrients, 6, 391-415. https://doi.org/10.3390/nu6010391

Jayaprakasha, G.K., Selvi, T., \& Sakariah K.K. (2003). Antibacterial and antioxidant activities of grape (Vitis vinifera) seed extract. Food Research International, 36, 117-122. $\quad$ https://doi.org/10.1016/S09639969(02)00116-3

Kang, Y.M. Lee, M., \& An, H.J. (2021). Oleanolic acid protects against mast cell-mediated allergic responses by suppressing Akt/NF-KB and STAT1 activation. Phytomedicine, 80, 153340. https://doi.org/10.1016/j.phymed.2020.153340

Kobra A., Reza H.H., Reyhaneh S., \& Atusa V. (2019). Antioxidant activity of aqueous extracts from Vitis vinifera's wastes. Novel Approches in Drug Designing Development, 4(5), 555646.

Lago-Vanzela, E.S., Da-Silva, R., Gomes, E., García-Romero, E., \& Hermosín-Gutiérrez, I. (2011). Phenolic composition of the edible parts (flesh and skin) of bordó grape (Vitis labrusca) using HPLC-DAD-ESIMS/MS. Journal of Agricultural and Food Chemistry, 59(24), 13136-13146. https://doi.org/10.1021/jf203679n
Lara, I., Heredia, A., \& Domínguez, E. (2019). Shelf life potential and the fruit cuticle: The unexpected player. Frontiers in Plant Science, 10, 770 10:770. https://doi.org/10.3389/fpls.2019.00770

Liu, T., Zhao, J., Ma, L., Ding, Y., \& Su, D. (2012). Hepatoprotective effects of total triterpenoids and total flavonoids from Vitis vinifera L. against immunological liver injury in mice. Evidence-Based Complementary and Alternative Medicine, 1-8. https://doi.org/10.1155/2012/969386

Orbán, N., Kozák I.O., Drávucz M., \& Kiss A. (2009). LC-MS method development to evaluate major triterpenes in skins and cuticular waxes of grape berries. International Journal of Food Science and Technology, 44, 869-873. https://doi.org/10.1111/j.1365-2621.2008.01902.x

Pensec, F., Paczkowski, C., Grabarczyk, M., Woźniak, A., \& Bénard-Gellon, M. (2014). Changes in the triterpenoid content of cuticular waxes during fruit ripening of eight grape (Vitis vinifera) cultivars grown in the upper Rhine Valley. Journal of Agricultural and Food Chemistry, 62, 7998-8007. https://doi.org/10.1021/jf502033s

Rockenbach, I.I, Gonzaga L.V., Rizelio V.M., Gonçalves A.E.S.S., Genovese M.I., \& Fett R. (2011a). Phenolic compounds and antioxidant activity of seed and skin extracts of red grape (Vitis vinifera L. and Vitis labrusca L.) pomace from Brazilian winemaking. Food Research International, 44(4), 897-901. https:// doi.org/10.1016/j.foodres.2011.01.049

Rockenbach, I.I, Rodrigues, E., Gonzaga L.V., Caliari, V., Genovese M.I., Gonçalves A.E.S.S., \& Fett, R. (2011b). Phenolic compounds content and antioxidant activity in pomace from selected red grapes (Vitis vinifera L. and Vitis labrusca L.) widely produced in Brazil. Food Chemistry, 127(1), 174-179. https:// doi.org/10.1016/j.foodchem.2010.12.137

Sabra, A., Netticadan, T., \& Wijekoon, C. (2021). Grape bioactive molecules, and the potential health benefits in reducing the risk of heart diseases. Food Chemistry, 12, 100149. https:// doi.org/10.1016/i.fochx.2021.100149

Santos, L.P., Morais, D.R., Souza, N.E., Cottica, S.M. Boroski, M., \& Visentainer J. V. (2011). Phenolic compounds and fatty acids in different parts of Vitis labrusca and Vitis vinifera grapes. Food Research International, 44(5), 1414-1418. https://doi.org/10.1016/j.foodres.2011.02.022

Samavardhana, K., Supawititpattana, P., Jittrepotch, N., Kongbangkerd, T., \& Rojsuntornkitti, K. (2015). Effects of extracting conditions on phenolic compounds and antioxidant activity from different grape processing byproducts. International Food Research Journal, 22(3), 1169-1179.

Shahidi, F., \& Ambigaipalan, P. (2015). Phenolics and polyphenolics in foods, beverages and spices: Antioxidant activity and health effects -A review. Journal of Functional Foods, 18, 820-897. http:/ / dx.doi.org/10.1016/i.jff.2015.06.018

Shao, D., Zhang, L., Du, S., Yokoyama, W., Shi, J., Li, N., \& Wang, J. (2016). Polyphenolic content and color of seedless and seeded shade dried Chinese raisins. Food Science and Technology Research, 22(3), 359-369. https://doi.org/10.3136/fstr.22.359

Singleton, V.L., \& Rossi, J.A. (1965). Colorimetry of total phenolics with phosphomolybdic-phosphotungstic acid reagents. American Journal Enology Viticulture,16(3), 144-158.

Tural, S., \& Koca, I. (2008). Physico-chemical and antioxidant properties of cornelian cherry fruits (Cornus mas L.) grown in Turkey. Scientia Horticulturae, 116(4), 362-366. https://doi.org/10.1016/j.scienta.2008.02.003

Wrolstad, R.E. (1976). Color and pigment analyses in fruit products. In: Station Bulletin 624, Agricultural Experiment Station Oregon State, Corvallis, OR, pp. 1-17.

Yamamoto, L.Y., Koyama, R., Assis, A.M., Borges, W.F., Oliveira, I.R., \& Roberto, S.R. (2015). Color of berry and juice of 'Isabel' grape treated with abscisic acid in different ripening stages. Pesquisa Agropecuária Brasileira 50(12), 1160-1167. https://doi.org/10.1590/S0100204X2015001200005

Zhang, Y., Xue, K., Zhao, E.Y, Li, Y., Yao, L., Yang, X., \& Xie, X. (2013) Determination of oleanolic acid and ursolic acid in Chinese medicinal plants using HPLC with PAH polymeric C18. Pharmacognosy Magazine, 9(36), 19-24. https:// doi.org/10.4103/0973-1296.117853 